\title{
Alterations in prostate morphogenesis in male rat offspring after maternal exposure to Di- $n$-butyl-phthalate (DBP)
}

\author{
Talita de Mello Santos ${ }^{a}, *$, Lívia Teresa Ribeiro da Silveira ${ }^{b}$, Jaqueline Carvalho Rinaldi ${ }^{b}$, \\ Wellerson Rodrigo Scarano ${ }^{\mathrm{b}}$, Raquel Fantin Domeniconi ${ }^{\mathrm{a}}$ \\ a Department of Anatomy, Institute of Biosciences, Univi Estadual Paulista/UNESP, Botucatu, SP, Brazil \\ ${ }^{\mathrm{b}}$ Department of Morphology, Institute of Biosciences, Univi Estadual Paulista/UNESP, Botucatu, SP, Brazil
}

\section{A R T I C L E I N F O}

\section{Article history}

Received 8 June 2016

Received in revised form 6 March 2017

Accepted 20 March 2017

Available online 21 March 2017

\section{Keywords:}

Di-n-butyl-phthalate (DBP) BMP-4

Testosterone

Androgen receptor

Antiandrogenic

Prostate development

$\alpha$-actin

\begin{abstract}
A B S T R A C T
Prostate morphogenesis is regulated by androgens hormones and modulated by morphogenetic proteins such as Bone Morphogenetic Proteins (BMPs). This study aims to investigate the effects on prostate development in male offspring and differentiation after gestational and lactational maternal exposure to Di- $n$-butyl-phthalate (DBP), an important environmental contamination. Pregnant Wistar rats received 100 or $500 \mathrm{mg} / \mathrm{kg}$ of DBP (DBP100 and DBP500), by gavage, from gestation day 15 (GD15) until postnatal day 21 (PND21). The pups were euthanized on PND1 and PND21. Anogenital distance and testosterone levels decreased in animals from exposed mothers (DBP100 and 500) on PND1. A three-dimensional reconstruction model of the prostatic urethra showed reduction in the prostatic buds in the DBP500 group. AR expression and $\alpha$-actin immunoreactivity decreased, and BMP-4 expression was lower on PND1 for DBP500. These results showed that DBP exposure, especially at a higher dose, delayed prostate morphogenesis by reducing the testosterone/AR axis and BMP-4 expression.
\end{abstract}

(c) 2017 Elsevier Inc. All rights reserved.

\section{Introduction}

Phthalate esters are widely used in industry as plasticizers and solvents, so they are present in many products, including latex adhesive, cellulose acetate plastic, personal care products, and in the coating of some oral medications. The way the products are exposed to the environment and pollution during the production process makes the phthalates an important group of environmental contaminants (International Program on Chemical Safety [IPCS] [1-3]). Human exposure to phthalates can occur by ingestion of contaminated water and food, inhalation of polluted air, use of certain medications, and dermal contact with lotions or cosmetics containing this additive [4].

About $90 \%$ of human exposure to the various types of phthalates occurs through food consumption, which could be contaminated by absorption of phthalates present in their packaging or during the food production process $[5,6]$. The presence of this ester on the environment is directly related to the modern lifestyle. Studies have shown that Di- $n$-butyl-phthalate (DBP) is present in human uri-

\footnotetext{
* Corresponding author.

E-mail addresses: talitamello.tms@gmail.com, talita_mellosantos@yahoo.com.br (T. de Mello Santos)
}

nary metabolites and seminal plasma in high concentrations, which explains the growing interest in evaluating its effects on humans and animals [7-9].

According to Mylchreest et al. [10], the lowest observed adverse effect level (LOAEL) dose of DBP in the male genital system of rats is $100 \mathrm{mg} / \mathrm{kg}[11,12]$, whereas literature shows that higher doses of $500-850 \mathrm{mg} / \mathrm{kg}$ induce more evident and clear effects in animals [13-16].

Maternal exposure to phthalates has shown effects on several stages of rodent development, most of them on the reproductive system of male offspring, such as: reduction of germ cell numbers, impaired sperm quality, reduced anogenital distance, cryptorchidism, hypospadias, decreased testosterone levels, and delayed onset of puberty, in addition to malformation of the epididymis, vas deferens, seminal gland and prostate in adulthood. These associated effects characterize DBP as a substance with potential anti-androgenic activity. Previous studies have shown that this ester produces a marked malformation of the male reproductive system by reducing fetal testicular testosterone production through alterations in the fetal Leydig-cells. In rats, near gestational day 15 (GD15), the start of the time window for reproductive development, Leydig-cells increase testosterone production, increasing testosterone levels. With this increase, 


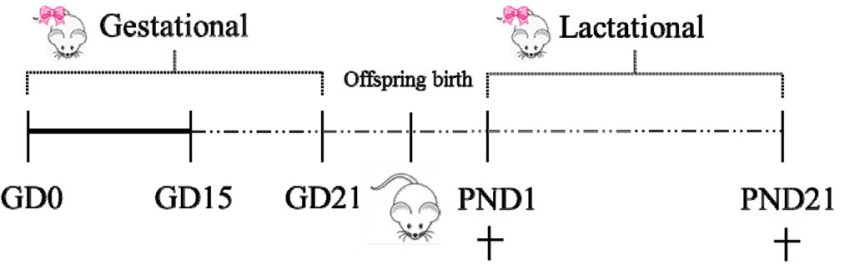

Fig. 1. Illustration of experimental design. Gestational day zero (GD0), 30 pregnant female rats were randomly separated into 3 groups ( $n=10$ animals/group): $\mathrm{CN}$ (Control), DBP100 and DBP500. From gestational day 15 (GD15) to postnatal day 21 (the end of the lactation period) pregnant females from the DBP100 and DBP500 groups were exposed to Di- $n$-butyl-phthalate at $100 \mathrm{mg} / \mathrm{Kg}$ and $500 \mathrm{mg} / \mathrm{Kg}$ respectively, by gavage. The $\mathrm{CN}$ group received corn oil. At birth of the offspring, some parameters were obtained from the male pups and they were then divided into two groups. One was killed on postnatal day 1 (PND1) and the other on postnatal day 21 (PND21).

\section{Testosterone levels (PND1)}

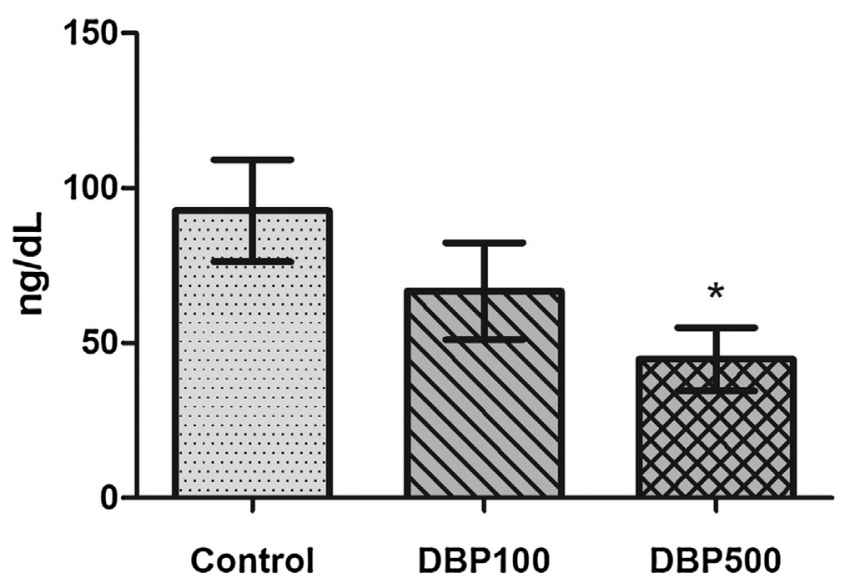

\section{Experimental Groups}

Fig. 2. Plasma testosterone levels in Negative Controls and DBP-exposed rats. Data expressed as mean \pm SEM. *p $<0.05$ Control vs. DBP500 (ANOVA+ Kruskal-Wallis). $\mathrm{n}=5$ pools- 4 animals/pool

androgen-dependent organs respond by masculinizing the tissues [2,10,11,17-26].

Androgens are important for physiological responses and are essential in development, differentiation, growth and function of the male reproductive organs. Prostate gland morphogenesis is androgen dependent and results from interaction between epithelium and mesenchyme (E-P) at different stages such as budding, branching and cell differentiation, which is also modulated by a range of growth factors [27-29]. Mesenchyme expresses AR and acquires the capacity to induce the sprouting of prostatic buds, ductal branching, and cytological and epithelial differentiation of prostate that occurs parallel to the development of stroma. One of the first stroma cells to differ is the mesenchymal cells in smooth muscle cells. After this cytodifferentiation, they can express $\alpha$ actin, a specific smooth muscle protein. And in the epithelium, basal cells are the first to differentiate and express p63. This protein has been shown to play a role in the regulation of epithelial cell development and differentiation [28,30-33].

Androgens also regulate morphogenetic proteins as Bone Morphogenetic Protein type 4 (BMP-4). BMP-4 is an important morphogenetic protein, expressed both in epithelial and mesenchymal cells, responsible for inhibiting cell proliferation during development. These proteins act before and during budding, branching and elongation of prostate ducts, being essential to the correct pat-
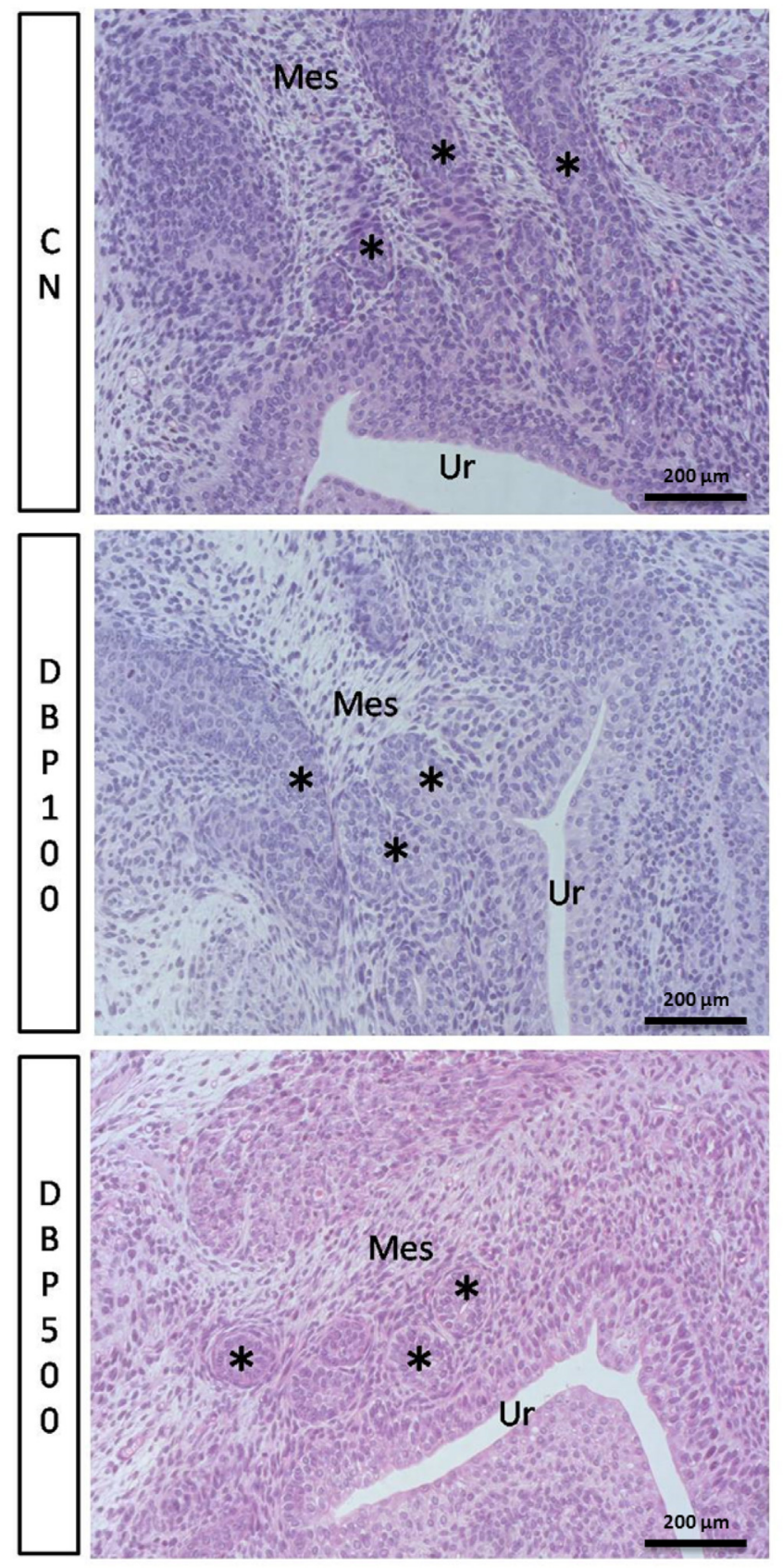

Fig. 3. Histological sections from the pelvic part of the urethra of $\mathrm{CN}$ and DBPexposed animals, stained with hematoxylin-eosin on the 1 st day after birth. Asterisk represents the prostatic buds; Ur: urethra, Mes: mesenchyme. 200X magnification.

tern of branching and subsequent cell differentiation of this gland $[17,34,35,27,36,37,28,38]$.

Some neonatal developmental changes that occur within the accessory sex organs, such as the prostate, are sensitive to androgen and anti-androgen substances. Changes in prostate morphogenesis patterns can interfere irreversibly with adult prostate morphophysiology, directly related to diseases associated with aging, such as prostatic cancer [39]. Thus, exposure to anti-androgen agents such as DBP during critical phases of development increases the risk of developing prostate diseases in adulthood [40].

Since DBP acts as an anti-androgen substance [23] and androgens are essential to prostate morphogenesis [17,28], in addition to the fact that different doses seems to cause different effects, the aim of this study was to investigate the effects of DBP on prostate devel- 


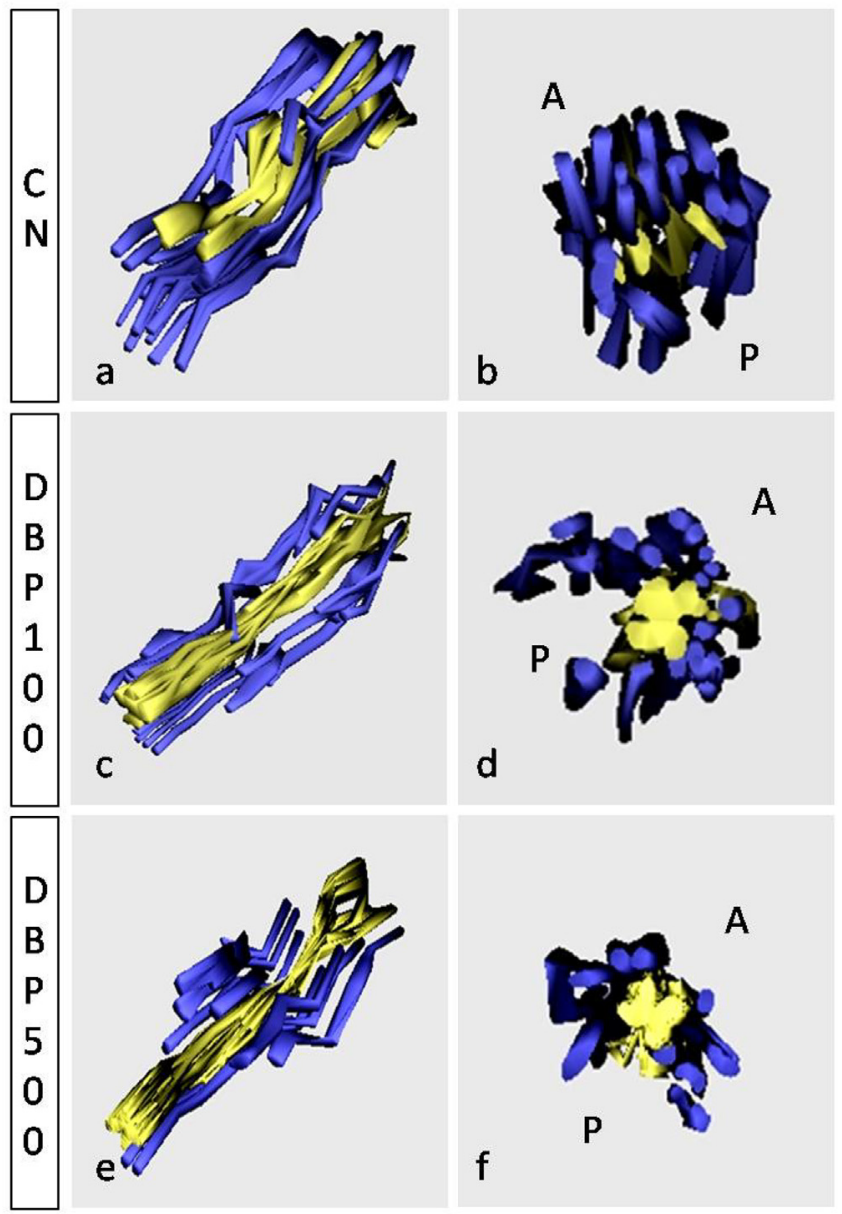

Fig. 4. Three-dimensional reconstruction of the prostatic buds and pelvic part of the urethra of CN (a-b), DBP100 (c-d) and DBP500 (e-f) male offspring on PND1. The prostatic buds (blue) appear around the pelvic part of the urethra (yellow). Figures $\mathrm{b}, \mathrm{d}$ and $\mathrm{f}$ represent a cross-sectional view of the generated image with the signaled anteroposterior axis (A-P). The images were constructed from histological serial sections of the pelvic part of the urethra (cuts of $5 \mu \mathrm{m}$ ) obtained from three animals in each experimental group. (For interpretation of the references to colour in this figure legend, the reader is referred to the web version of this article.)

opment regarding regulatory proteins that mediate this process and to analyze gland differentiation and maturation.

\section{Material and methods}

\subsection{Experimental design}

Adult female (60 days of age, $n=30$ ) and male (90 days of age, $n=15$ ) Wistar rats were obtained from the Central Biotherium of São Paulo State University (UNESP) and housed in polypropylene cages $(43 \mathrm{~cm} \times 30 \mathrm{~cm}$ X $15 \mathrm{~cm}$ ) with laboratory grade pine shavings as bedding. Rats were maintained under controlled temperature $\left(22 \pm 2{ }^{\circ} \mathrm{C}\right)$ and relative humidity $(55 \pm 10 \%)$ and lighting conditions (12:12-h photoperiod). Balanced rat chow (NUVILAB ${ }^{\circledR}$ CR1-Nuvital-PR - composition $(\mathrm{g} / \mathrm{Kg})$ : cornstarch (480), casein (71.5), dextrinized cornstarch (159), sucrose (121), soybean oil (70), microcellulose (50), mineral mix-AIN-93-G-Mx (35), vitamin mix-AIN-93-Vx (10), L-cystine (1), choline chlorhydrate (2,5)) and filtered tap water were provided ad libitum. The experimental protocol was designed following Brazilian laws and was approved by the Ethics Committee on Animal Use at the Institute of Biosciences of Botucatu (CEUA: protocol $n^{\circ} 546$ ).
Two female rats were mated with one male during the dark period of the light/dark cycle, and vaginal smears were taken on the following days. The day that sperm was detected in the vaginal smear was considered gestational day zero (GD 0). Pregnant females were randomly allocated into 3 experimental groups $(n=10)$ and exposed daily to Di- $N$-butyl-phthalate $\left(\right.$ SUPELCO $^{\circledR},{ }^{8}$ BELLENFONTE, PA, USA. Molecular Formula: C16H22O4; Molecular Weight: 278.35; Catalog NO.: 48559; Lot NO.: LB77544; Purity $99,9 \%) \quad 100 \mathrm{mg} / \mathrm{kg}$ (DBP100), Di- $N$-butyl-phthalate $500 \mathrm{mg} / \mathrm{kg}$ (DBP500) or corn oil (negative control group, $\mathrm{CN}$ ), by gavage between GD 15 and PND21, during a part of the gestational period and for the entire lactational period. The male pups were thus exposed to DBP through the placenta and by breast-feeding during this part of the gestational period and the entire lactational period. These periods correspond to early and intermediate morphogenesis of rat prostates [34]. Pregnant females were housed in individual cages, weighed daily to calculate the DBP volume to be administered each day, and observed to analyze signals of clinical toxicity.

After birth, the litter size was standardized to eight pups per mother, preferentially males, in all the experimental groups. Anogenital distance (AGD) was measured using a digital caliper $\left(0-150 \mathrm{~mm}\right.$, Western $\left.{ }^{\circledR}\right)$ and body weight was obtained using a precision scale. In each litter, four males were used to obtain a mean for AGD and body weight resulting in ten means by group for these parameters. Anogenital distance ( $\mathrm{mm}$ ) was divided by the cube root of the body weight in order to obtain the relative AGD of all male offspring. On PND1, 2-4 male pups per litter and on PND21, two males per litter were killed by decapitation to evaluate possible gestational and lactational effects that exposing mothers to DBP has the initial development of prostatic buds and on the process of branching and differentiation of epithelium and stroma, respectively (Fig. 1).

\subsection{Hormonal serum analysis}

On PND1 and PND21, animals were anesthetized and killed by decapitation. Blood was collected from ruptured cervical vessels and stored in dry preservative-free vials for hormone measurements. The serum was obtained after centrifugation (3000g, $20 \mathrm{~min}$, at $4{ }^{\circ} \mathrm{C}$ ) and then frozen at $-80^{\circ} \mathrm{C}$ until the analyses. Serum sample "pools" were created on PND1 ( 4 animals/pool; $n=5$ pools/group) due to the small amount of blood per animal. Ten serum samples were analyzed from PND21 animals. The number of samples was determined by the availability of males from different litters, and based on the volume of serum required for analysis. Testosterone serum levels were determined by chemiluminescence (Elecsys, Roche $^{\circledR}$ ) using a Testosterone Assay Kit (sensitivity $20 \mathrm{ng} / \mathrm{dL}$ ). All samples were dosed in the same assay, to avoid inter-assay errors. The intra-assay variation was $2.05 \%$ and the results were expressed in $\mathrm{ng} / \mathrm{dL}$.

\subsection{Immunohistochemistry}

The pelvic part of the urethra (PND 1) from 1 to 2 male pups per litter and the ventral prostate (PND 21) from 1 animal/litters were collected and fixed in methacarn, cleared in xylene, and then embedded in Paraplast. Serial sections of $4 \mu \mathrm{m}$ were obtained in automatic rotary microtome and collected in silanized slides for histological and immunohistochemical analysis. The slides from the methacarn-fixed material were subjected to antigen retrieval in a humid environment (electric pot) at $100^{\circ} \mathrm{C}$ in Tris/0.1 M EDTA pH 9.0 for $30 \mathrm{~min}$. After washing in distilled water, the sections were subjected to the blocking of endogenous peroxidase (hydrogen peroxide at $3 \%$ in methanol) for $15 \mathrm{~min}$. The slides were then subjected to blocking of nonspecific protein with skim milk at 3\% in PBS 

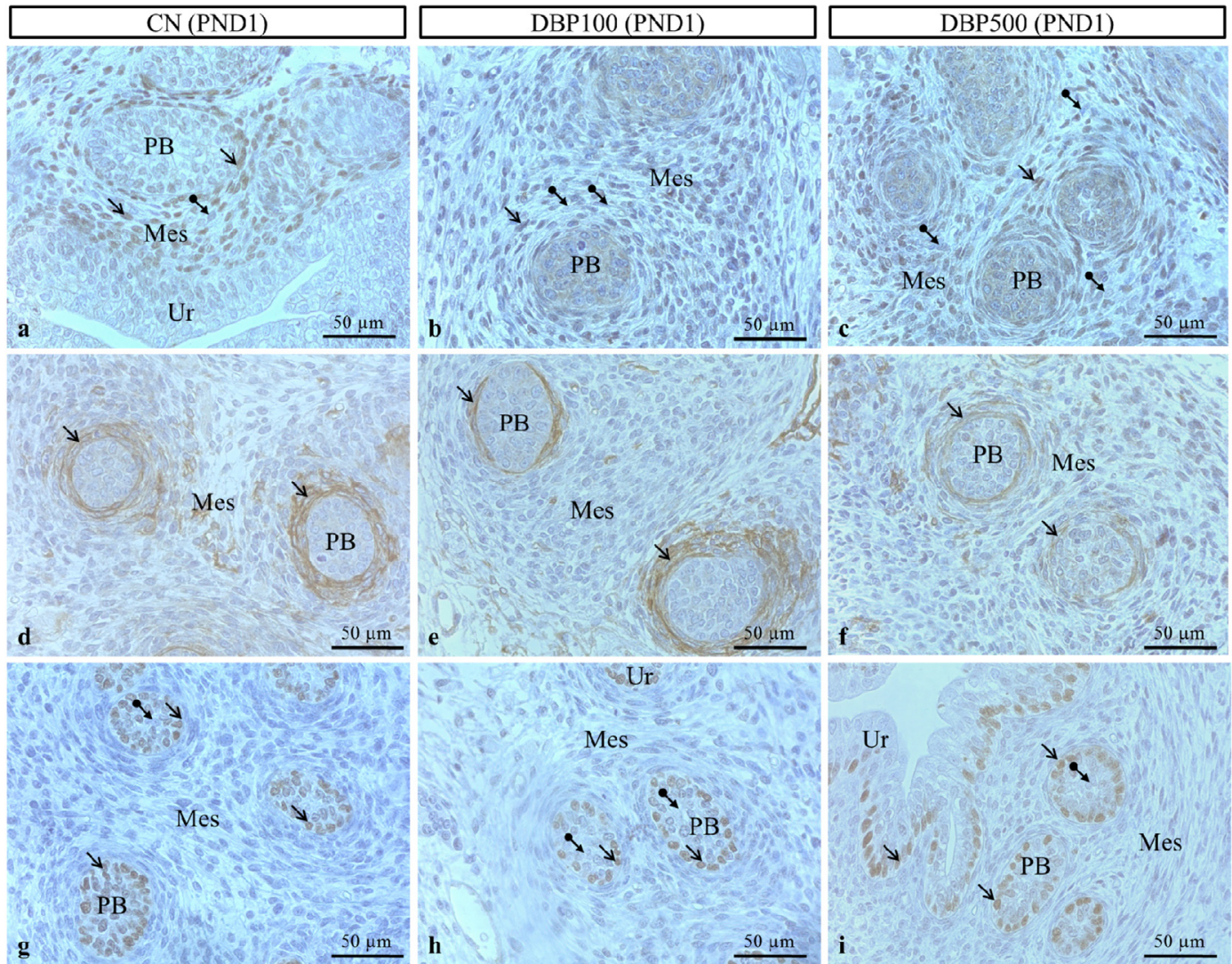

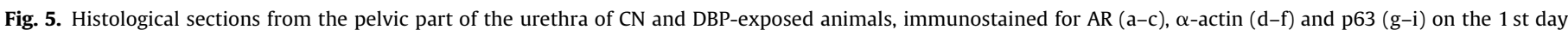

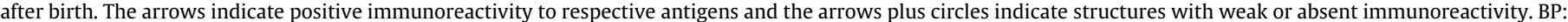
prostatic buds; Ur: urethra, Mes: mesenchyme. Scale bar $=50 \mu \mathrm{m}$.

for $1 \mathrm{~h}$. Next, the sections were incubated overnight (at $4{ }^{\circ} \mathrm{C}$ ) with primary antibodies of the anti-AR- Androgen receptor (06-608; Anti-Rabbit; concentration 1:100; EMD-Milipore Corp. ${ }^{\circledR}$, Billerica, Ma, USA); anti-P63-basal progenitor cells (MAB4135; Anti-Rabbit; concentration 1:100, EMD-Milipore Corp. ${ }^{\circledR}$, Billerica, Ma, USA); and anti- $\alpha$-actin- smooth muscle cells (ab6594; Anti-Rabbit concentration 1:100; Abcam Inc. ${ }^{\circledR}$, Cambridge, Ma, USA). After incubation with primary antibodies, the sections were washed in PBS and then incubated with anti-rabbit secondary HRP antibody (ab97051; concentration 1:200, Abcam Inc. ${ }^{\circledR}$, Cambridge, Ma, USA) for two hours at room temperature. The reaction was visualized with DAB chromogen (3, 3'-diaminobenzidine tetrahydrochloride; Sigma-Aldrich Co. ${ }^{\oplus}$, St. Louis, Mo, USA) and counterstained with Hematoxylin for $1 \mathrm{~min}$. In order to confirm the specific reaction, negative controls were used, excluding the primary antibody incubation (data not shown).

\subsubsection{Determination of progenitor basal cell index}

Progenitor basal cells ( 633 positive) were marked by immunohistochemistry and a labeling index was estimated in the bud and prostatic epithelium on PND1 and PND21, respectively. Next, 5 slides (histologic sections of 5 animals from different litters; $n=5$ ) from CN, DBP100 and DBP500 were randomly chosen and microscopic fields were digitized using an image analyzing system (Axio Vision 4.8) coupled with an AxioLab.Al, Zeiss photomicroscope (Carl Zeiss Int., Oberkochen, Germany). On PND 21, five histological fields per slide were analyzed, while on PND 1, the entire prostatic bud (all buds present in the slide) was evaluated, since a single picture was able to include the whole structure. Approximately 1500 cells were counted on PND 1 and 700 cells on PND 21. The P63 positive cells index was determined by dividing the number of stained cells by the number of cells analyzed and finally the value was multiplied by 100 for each animal at both ages and in all experimental groups.

\subsubsection{Determination of thickness of smooth muscle layer}

Five slides (histologic sections of 5 animals from different litters; $\mathrm{n}=5$ ) from CN, DBP100 and DBP500 (at both ages) were randomly chosen to obtain 50 digitized images per group (10 microscopic fields per animals) using an image analyzing system (Axio Vision 4.8) coupled with an AxioLab.Al, Zeiss photomicroscope (Carl Zeiss Int., Oberkochen, Germany). The thickness of the smooth muscle layer of prostatic buds (PND 1) and around the prostatic acini (PND 21 ) were then measured using Image ${ }^{\circledR}$ Windows ${ }^{\circledR}$ software. The values obtained for each group were compared to each other at both ages.

\subsection{Serial sections and three-dimensional (3-D) reconstruction}

The pelvic part of the urethra of three animals (from different litters) from the CN, DBP100 and DBP500 groups were histologically processed and serial sections of $4 \mu \mathrm{m}$ were obtained and stained with hematoxylin and eosin (HE) on PND1. Using free software called Reconstruct, developed by the National Institutes of Health and the Human Brain (Bethesda, MD, USA), the images were captured and processed in Windows ${ }^{\circledR}$. After alignment of the image, the urethra and prostatic buds were isolated in each image and then processed to obtain the interface in each section, generating a three dimensional (3-D) model, similar to that described by Pinho 


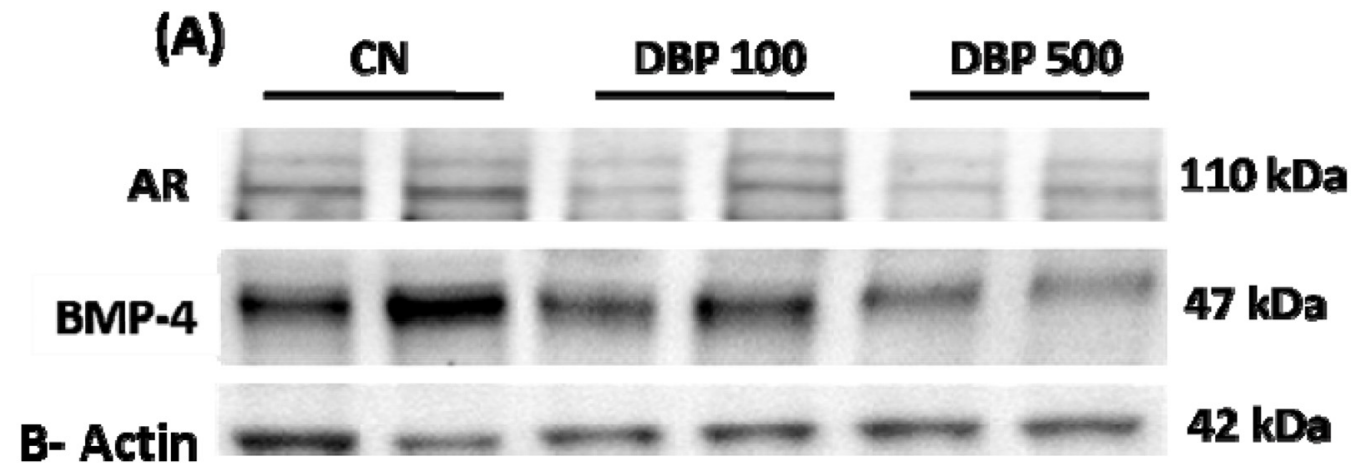

(B)

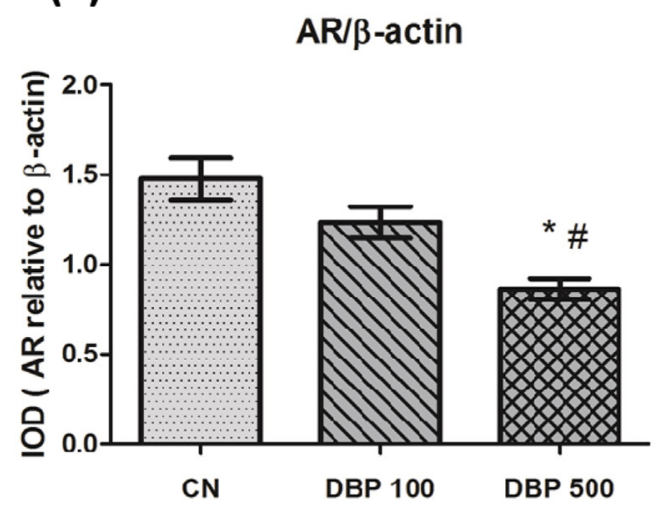

Experimental Groups
(C)

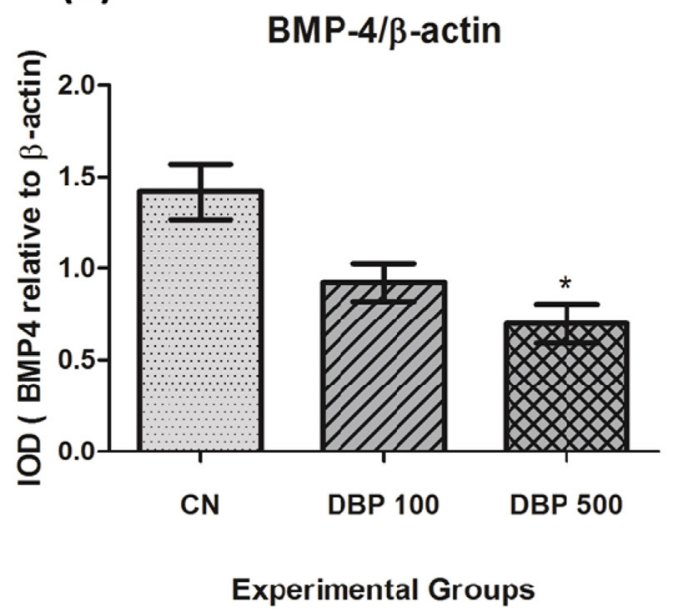

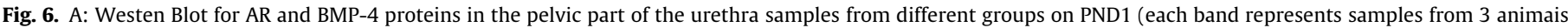

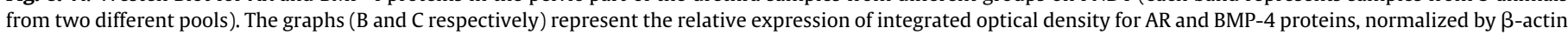

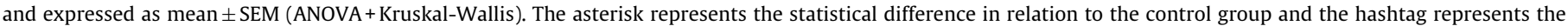
statistical difference between exposed groups ( $\mathrm{p}<0.05$ ), $\mathrm{n}=4$ pools ( 3 animals/pool).

et al. [41]. It is important to mention that this software is not able to capture blind spots, so the images show blunt ends at the edges.

\subsection{Western blot}

The pelvic part of the urethra (PND1; 1-2 animals/litter) and the ventral prostate (PND21; 1 animal/litter) were collected and the samples were snap-frozen in liquid nitrogen and stored at $-80^{\circ} \mathrm{C}$, to be analyzed using the Western Blotting technique. For PND1, sample "pools" (3 animals/pool: 4 pools per group) were created due to the small size and weight of the urethra pelvic part, and for PND 21, samples of the ventral prostate of 6 animals per group were analyzed individually. Frozen samples were homogenized at $4{ }^{\circ} \mathrm{C}$ in RIPA buffer (BioRad ${ }^{\circledR}$, USA) with protease inhibitor (Sigma-Aldrich $^{\circledR}$, USA) in Tureaux type homogenizer for three 5-s cycles. The homogenate material was centrifuged at $15.000 \mathrm{rpm}$ for 20 min at $4{ }^{\circ} \mathrm{C}$ and the supernatant was collected. The protein quantification was performed as described by Bradford [42] in ELISA plates with 96 wells, and read in an ELISA reader $(595 \mathrm{~nm})$. Aliquots (70 $\mu$ g protein) were treated with buffer solution to run gel (Laemli Sample Buffer - BioRad ${ }^{\circledR}$ ) and $\beta$-mercaptoethanol at $95^{\circ} \mathrm{C}$ for $5 \mathrm{~min}$. The proteins were then separated by vertical electrophoresis (Mini-Protean, BioRad ${ }^{\circledR}$ ) polyacrylamide gel SDS-PAGE and after the electrophoresis, transferred to a nitrocellulose membrane in a wet transfer system. Nonspecific protein binding was blocked with $3 \%$ skimmed milk in TBST buffer for $1 \mathrm{~h}$ at room temperature. The membranes were then incubated overnight with primary antibodies: AR (clone 06-608; Anti-Rabbit concentration 1:500; EMD-Milipore Corp. ${ }^{\circledR}$, Billerica, Ma, USA); BMP4 (clone: ab39973; Anti-Rabbit concentration 1:500, Abcam Inc. ${ }^{\circledR}$, Cambridge, Ma, USA); and $\beta$-actin (clone: SC47778; Anti-Goat concentration 1:800; Santa Cruz Biotechnology ${ }^{\circledR}$, Santa Cruz, CA, USA), all of which were diluted in $1 \%$ BSA in TBST. Subsequently, the membranes were washed in TBST for three 10-min cycles, incubated for $2 \mathrm{~h}$ with specific HRP secondary antibody (clone: ab97051, IgG goat-anti rabbit concentration 1:1000, Abcam Inc. ${ }^{\circledR}$, Cambridge, Ma, USA; clone: a5420; IgG rabbit-anti goat concentration 1:4000, SigmaAldrich Co. ${ }^{\circledR}$, St. Louis, Mo, USA), diluted in $1 \%$ BSA in TBST, and then washed in TBST for three 10-min cycles. Immunoreactive components were revealed using a luminescence kit (Amersham ${ }^{\mathrm{TM}}$ ELC Select ${ }^{\mathrm{TM}}$ Western Blotting Detection Reagent, GE Healthcare ${ }^{\circledR}$, UK) and the optical density of each band was measured using Image ${ }^{\circledR}$ Windows ${ }^{\circledR}$ software, normalized by $\beta$-actin density.

\subsection{Statistical analysis}

Quantitative data were compared among experimental groups using GraphPad Prism ${ }^{\circledR}$ software. Biometric parameters were evaluated using ANOVA and Dunnett's test, and the other parameters were evaluated using the Kruskal-Wallis test, followed by Dunns test. Data were presented as mean \pm standard error of mean (SEM). Differences were considered significant when $\mathrm{p}<0.05$. On PND1; AGD, body weight and testosterone serum levels were obtained from 4 males/litter (randomly selected). To other parameters in 

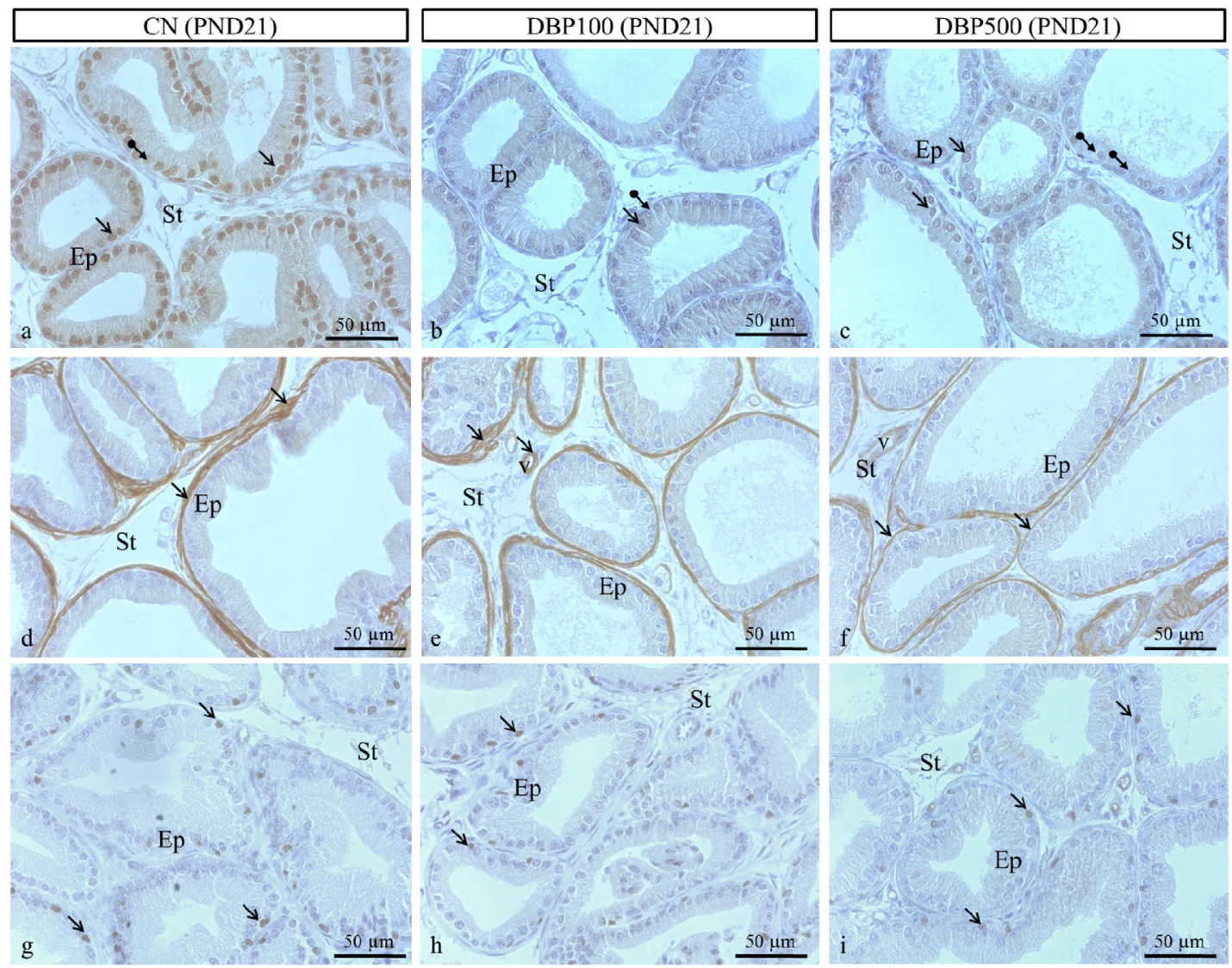

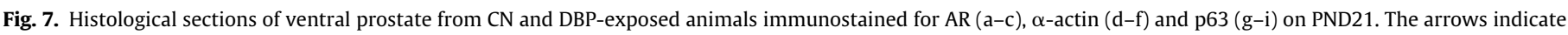

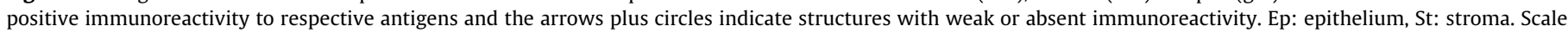
bar $=50 \mu \mathrm{m}$.

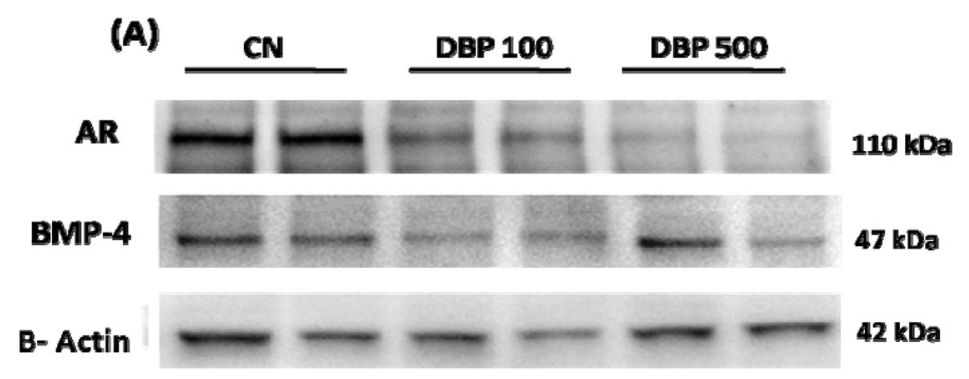

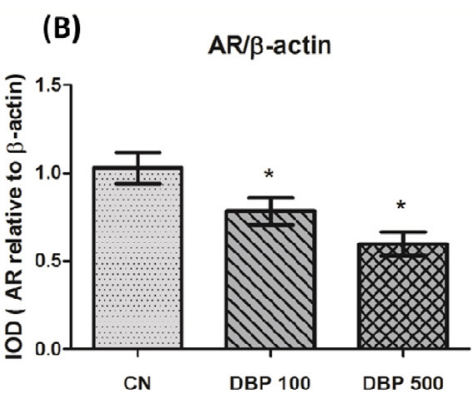

Experimental Groups

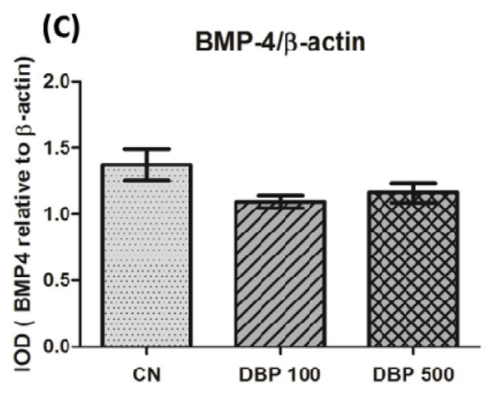

Experimental Groups

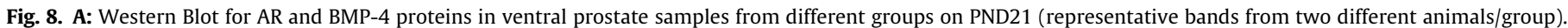

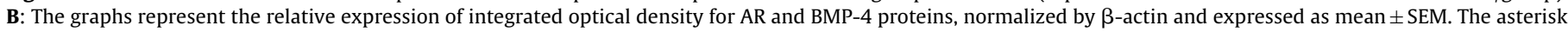
represents the statistical difference in relation to the control group $(\mathrm{p}<0.05), \mathrm{n}=6$ animals/group. 
both ages, results were obtained using 1-2 males/litter (randomly chosen), where the litter was used as the unit of measure into the experimental groups, the analysis was based on litter means.

\section{Results}

\subsection{Postnatal day 1 (PND1)}

Absolute and relative anogenital distance (AGD) was lower in both DBP-exposed groups compared to the negative control, while there was no difference in body weight among the animals from all experimental groups (Table 1 ).

Testosterone serum levels were significantly lower in the DBP500 group compared to the CN group (Fig. 2).

Histological findings showed that the epithelial buds start to arise from the ventral part of the pelvic urethra, and their elongation and branching begin from the urethra to the distal part of the urogenital mesenchyme (Fig. 3). The pattern of epithelial budding was similar across experimental groups, however, the three-dimensional reconstruction model showed that both the number and length of buds in the DBP500 group were qualitatively lower than the CN and DBP100 groups (Fig. 4).

AR immunoreactivity was observed mainly in the mesenchymal cells that surround the prostatic buds. In both the DBP-exposed groups (DBP100 and DBP500), there was a high heterogeneity in the proportion of AR-positive cells compared to AR-negative or ARweakly stained cells (Fig. 5a-c).

Immunostaining of $\alpha$-actin was observed in cells surrounding the prostatic buds region, where the mesenchymal cells differentiated into smooth muscle cells. There was less immunostaining in this region among the DBP-exposed animals compared to the $\mathrm{CN}$ group (Fig. 5d-f and Table 2). The measurement of smooth muscle layer thickness was significantly lower in DBP500 than in CN (Table 2). Immunostaining for p63 protein was restricted to the epithelial cells from the prostatic buds and therefore absent in the mesenchymal cells surrounding the prostatic buds. There was no difference in the number of p63 positive cells between the experimental groups (Fig. 5g-i and Table 2).

Western blot analysis showed a reduction in AR expression in DBP500 animals compared to CN and DBP100. BMP-4 expression was reduced in DBP500 animals compared to the negative controls (Fig. 6).

\subsection{Postnatal day 21 (PND21)}

Body weight, ventral prostate and testis weights did not differ significantly among the groups (Table 3 ).

Serum testosterone levels were lower than $20 \mathrm{ng} / \mathrm{dL}$, hindering their measurement and comparison between experimental groups (data not shown).

Histological analyses showed no difference in the proportion of ducts, acini and stroma across all experimental groups (Fig. 7c). Immunostaining for AR on ventral prostate was predominant in the nucleus of epithelial cells. On PND21, DBP-exposed animals presented a high heterogeneity of immunoreactivity between positive cells and weak or negative staining cells compared to $\mathrm{CN}$ animals (Fig. $7 a-c)$.

Immunostaining for $\alpha$-actin of smooth muscle cells that surround the acini was less intense in the DBP500 group compared to the $\mathrm{CN}$ and DBP100 groups. A decrease in muscle layer thickness was evident in the DBP500 group compared to the other groups (Fig. 7d-f and Table 2).

P63 immunoreactivity was restricted to the basal compartment of ventral prostate epithelium. There was no difference in the num- ber of basal stained cells among the experimental groups (Fig. 7g-I and Table 2).

There was a decrease in AR expression in the DBP-exposed groups compared to the negative control group, whereas BMP-4 protein expression showed no difference between experimental groups (Fig. 8).

\section{Discussion}

Many industrial chemical contaminants, like phthalates, can be passed from pregnant females to their babies through the placenta and via breast-feeding, and the exposure of mothers to these chemicals, in various doses, can alter the morphogenesis of the systems and organs of their offspring, including the urogenital tract [14,18,43-45].

In rodents, most studies tend to expose the animals to greater or equal to $500 \mathrm{mg} / \mathrm{kg}$, which is considered a high dose of phthalates, and effects on the male reproductive system development appear more pronouncedly. However, a few studies have showed some effects on the male reproductive system even with lower doses, such as $100 \mathrm{mg} / \mathrm{kg}[11,46,14,15,25,47-49]$. In this study, two DBP doses were tested (100 and $500 \mathrm{mg} / \mathrm{kg}$ ), in order to observe the effect of this chemical on prostate development in rats. The effects of prenatal exposure on the initial development of the gland were found to continue into the lactational period.

AGD, areola/nipple regression, testicular descent and preputial separation in male rats are androgen dependent factors, sensitive to endocrine disruptors such as DBP, particularly when exposure occurs in-uterus $[22,50,51]$. Changes in these parameters could indicate a delayed onset of puberty, impaired sexual behavior, or even infertility in adulthood $[21,52,53]$. Exposure to DBP did not alter body weight, but it reduced relative AGD and testosterone levels, mainly in DBP500 compared to $\mathrm{CN}$, confirming the anti-androgen role of DBP on reproductive tract development $[10,16,51,54,55]$. It has been demonstrated that rats ventral prostate is adequate for testing of the endocrine disruptor due to its extreme dependency on androgen stimulation and high susceptibility to estrogenic stimulation [17,56,57].

When DBP-exposed animals were compared with their respective controls at PND1 and PND21, no changes to the body, ventral prostate or testicle weights were observed. These results suggest that exposure to DBP ( 100 and $500 \mathrm{mg} / \mathrm{kg}$ ) did not cause any signs of fetal or postnatal systemic toxicity. Several studies similar to this one (data not shown) reported that pregnant animals exposed to different doses of DBP did not present significant effects on maternal reproductive parameters $[11,58,55]$.

Prostate gland morphogenesis is androgen dependent and results from interaction between epithelium and mesenchyme (E-P), which is modulated by a range of growth factors [27-29]. Mesenchyme expresses AR and acquires the capacity to induce the sprouting of prostatic buds and ductal branching. Cytological and epithelial differentiation of prostate occurs in parallel to the development of stroma [28,30-32]. In this study, the pattern of epithelial budding and AR location by immunostaining were similar across the groups and the AR was especially marked in mesenchymal cells that surround the prostatic buds.

DBP, at $500 \mathrm{mg} / \mathrm{kg}$, was able to promote a reduction in AR protein levels, decreasing the length of prostatic buds, which was qualitatively observed in the three-dimensional reconstruction. DBP100 and DBP500 animals presented a dose-dependent reduction in serum testosterone levels when compared to $\mathrm{CN}$. Toxicological studies have shown that in-uterus exposure to certain phthalate esters, such as DBP, results in a range of reproductive abnormalities in male offspring. In rodents, some of these effects are associated with suppression of the expression of steroidogenic enzymes, lead- 
Table 1

Biometric parameters of experimental groups on PND 1.

\begin{tabular}{|c|c|c|c|}
\hline \multirow[b]{2}{*}{$\underline{\text { Parameters }}$} & \multicolumn{3}{|c|}{ Experimental Groups } \\
\hline & $\mathrm{CN}(\mathrm{n}=10)$ & DBP100 $(n=10)$ & DBP500 $(n=10)$ \\
\hline Body weight (g) & $7.46 \pm 0.27$ & $6.71 \pm 0.23$ & $6.75 \pm 0.25$ \\
\hline Absolute Anogenital Distance (mm) & $4.12 \pm 0.11$ & $3.35 \pm 0.21^{*}$ & $2.98 \pm 0.17^{*}$ \\
\hline Relative Anogenital Distance ( $\mathrm{mm} / \mathrm{g})$ & $0.5668 \pm 0.034$ & $0,4619 \pm 0,02^{*}$ & $0,4469 \pm 0,027^{*}$ \\
\hline
\end{tabular}

Table 2

Number of p63 positive cells and smooth muscle layer thickness on PND1 and PND21.

\begin{tabular}{|c|c|c|c|c|c|c|}
\hline \multirow[b]{3}{*}{$\underline{\text { Parameters }}$} & \multicolumn{6}{|c|}{ Experimental Groups } \\
\hline & \multicolumn{3}{|l|}{ PND1 $(n=5)$} & \multicolumn{3}{|l|}{ PND21 $(n=5)$} \\
\hline & $\mathrm{CN}$ & DBP100 & DBP500 & $\mathrm{CN}$ & DBP100 & DBP500 \\
\hline p63 positive cells (\%) & $71.96 \pm 4.88$ & $68.75 \pm 3.25$ & $57.18 \pm 4.83$ & $75.12 \pm 1.53$ & $60.23 \pm 4.76$ & $57.59 \pm 6.48$ \\
\hline Smooth muscle layer $(\mu \mathrm{m})$ & $133.9 \pm 16.84$ & $83.77 \pm 11.29$ & $40.95 \pm 2.08^{*}$ & $48.65 \pm 6.15$ & $33.40 \pm 2.09$ & $21.06 \pm 1.49^{*}, \#$ \\
\hline
\end{tabular}

Data expressed as mean \pm SEM

* Statistical difference in relation to control group.

\# Statistical difference in relation to DBP100 group ( $\mathrm{p}<0.05)$.

ing to physiological features indicative of impaired androgen action and inducing changes in the functions of Leydig cells, altering fetal androgen levels $[59,17,18,25,54]$.

Parks et al. [55] exposed pregnant rats to $750 \mathrm{mg} / \mathrm{kg} / \mathrm{day}$ of Diethylhexyl Phthalate (DEHP), a phthalate similar to DBP, from GD14 to PND3. For the first time, a reduction in testicular and whole-body testosterone levels was observed in male offspring during a critical period of sexual differentiation, which resulted in malformations of androgen-dependent tissues in these animals in adulthood.

Using the same DEHP protocol tested by Parks et al. [55,48], Veeramachaneni and Klinefelter [60] found changes in individual proteins known as cellular differentiation and migration factors were related to the ability of fetal Leydig cells to produce testosterone. These proteins are also part of a network of pathways, where they are directly or indirectly regulated by estradiol. The authors observed that exposure of rats to estradiol during the gestational period resulted in alterations of the testis and accessory sex organs of male offspring, similar to those found after phthalate exposure [61]. The similarity between the results found with estradiol and phthalate treatment may be associated with disruption of the androgen/estrogen balance during fetal development in both cases $[59,62]$.

Perez et al. [63] showed that the exposure to synthetic estrogens during critical periods of development affects the expression of steroid hormones receptors and alters the hypothalamicpituitary-gonadal (HPG) axis, which may cause changes in gonadal steroidogenesis and sex hormone production [64]. Since the pubertal period is associated with an enhancement of steroid hormone levels [65,66], the development of reproductive system can be influenced by environmental endocrine disruptor chemicals (EDCs), such as the phthalates [67]. It can cause reproductive function alterations and premature reproductive aging [68], and it predisposes rodents [69] and humans [70] to prostate cancer. However, it is important to emphasize that phthalates are not AR antagonists, rather, they act as an anti-androgenic substance during fetal life, reducing testosterone levels in rat fetuses [19,25,54].

During the perinatal period, buds and prostatic ducts are compact and the canalization process of these structures only starts after the birth of a male. Canalization starts near the proximal urethra and continues distally toward the end of the acini. At the same time, basal and secretory epithelial cells initiate the cellular dif-
Table 3

Biometric parameters of experimental groups PND21.

\begin{tabular}{llll}
\hline & \multicolumn{2}{l}{ Experimental Groups } \\
\cline { 2 - 4 } Parameters $(\mathrm{g})$ & $\mathrm{CN}(\mathrm{n}=10)$ & $\mathrm{DBP} 100(\mathrm{n}=10)$ & $\mathrm{DBP500}(\mathrm{n}=10)$ \\
\hline Body Weight & $45.13 \pm 2.32$ & $48.40 \pm 3.93$ & $47.61 \pm 2.11$ \\
Ventral Prostate Weight & $0.033 \pm 0.0034$ & $0.035 \pm 0.00368$ & $0.034 \pm 0.0018$ \\
Right Testicle Weight & $0.145 \pm 0.0044$ & $0.175 \pm 0.0118$ & $0.154 \pm 0.0067$ \\
\hline
\end{tabular}

Data expressed as mean \pm SEM. $\mathrm{p}<0.05$.

ferentiation process, evidenced by the presence of protein p63 on basal cell nuclei [32,33].

According to Peehl et al. [71], a differentiated prostatic epithelium is composed of five different cell types, including secretory epithelial cells that express high AR levels and epithelial basal cells that have high proliferative activity. There is a connective stroma surrounding the glandular parts of the prostate, consisted of smooth muscle cells arranged concentrically that exert a crucial role on the contraction during ejaculation [72,73]. It is important to emphasize that development of the prostatic epithelium manages the differentiation of mesenchymal cells in smooth muscle. Stromal cells are the first cells to express AR and respond to an increase of testosterone produced by the fetal testis, initiating the synthesis of paracrine factors that induce epithelium proliferation and differentiation [74].

The immunoreactivity of $\alpha$-actin indicated the presence of cells surrounding the prostatic bud region where the mesenchymal cells are already differentiated into smooth muscle cells [75]. As observed in both ages, immunoreactivity for $\alpha$-actin was weaker in the DBP-exposed groups, particularly in the DBP500 group compared to $\mathrm{CN}$. This data was confirmed by measuring the thickness of the prostate smooth muscle layer ( $\alpha$-actin positive layer), which was less in DBP500 animals than in the other groups. These results suggest a delay in the differentiation of smooth muscle cells in the DBP-exposed groups, which certainly interferes with paracrine epithelial-stromal interaction, delaying the development and maturation of epithelial cells. It emphasizes the inhibitory role of the $500 \mathrm{mg}$ dose $[14,16,47]$ and its ability to affect the contractile function of the mature prostate [76]. In turn, p63, selectively expressed in the basal cells, showed no difference between the experimental groups, demonstrating that basal stem cells are capable of surviving in a low androgen environment, as stated by Bonkhoff (1996) [33]. 
Prostatic development, including appendicular patterning and cell differentiation, is regulated by organ-specific morphoregulatory genes and molecules that are described as essential to embryogenesis, such as SonicHedgehog (Shh), Wnts, Fibroblast growth factor (Fgfs) and Bone morphogenetic proteins (BMPs) $[28,38,39,77]$. These proteins control development, resulting in complex branching patterns, which is essential in this period. Thus, they are the major signaling pathways that regulate the development of the prostate in rodents $[27,78]$.

BMPs such as BMP-4 and BMP-7 act as growth factor modulators in urogenital sinus (UGS) development, inhibiting both epithelial growth and branching [79,80]. Of all the BMPs, bone morphogenetic protein type 4 (BMP4) is widely expressed in the adjacent mesenchyme in the most proximal portion of the prostatic buds, and this expression remains active from ED17 and throughout the budding process [27].

Our results showed a reduction in BMP-4 protein expression in the DBP500 group on PND1. Since BMP-4 is a key factor in branching and cytodifferentiation, these results suggest that higher DBP doses may delay the formation of initial epithelial buds, and interfere with duct sizes and branching. Furthermore, smooth muscle cells and AR expression in epithelial cells were reduced in this age, suggesting that maturation and differentiation of the prostatic epithelium and stroma may also have been delayed by this dose [27,38,39].

Another important aspect observed in newborn animals is the direct relation between the expression of AR and BMP-4 proteins. Our data showed that both are reduced in DBP500, a result which is in accordance with previous reports indicating that AR can regulate the expression of BMP-4 in mesenchymal cells [28,38].

The reduced expression of BMP-4 was not observed on PND21. The animals exposed to $500 \mathrm{mg}$ of DBP presented similar levels of this protein as the controls. This similarity can be explained by the local levels of BMP-4 expression, which are normally lower during the postnatal period $[27,38,39]$.

The importance of investigating the regulation of prostate growth and function is due, at least in part, to many pathological complications that can affect this gland. The prostate is the installation site of various types of inflammatory and infectious conditions, as well as benign and malignant proliferative changes in aging males [81].

In conclusion, this study showed that both DBP doses, but especially the high dose, interfered with prostate morphogenesis in the male offspring of mothers exposed to DBP during pregnancy and lactation. Based on three-dimensional reconstructions, we can infer that at higher doses, DBP delays the branching of buds. Thus, studies investigating the effects of DBP on the prostate are needed, since Di- $n$-butyl-phthalate is an important environmental contaminant that acts as an endocrine disruptor and is present in many products directly related to the modern lifestyle.

\section{Conflict of interest statement}

The authors declare that there are no conflicts of interest.

\section{Acknowledgement}

The authors would like to acknowledge Mr. Gelson Rodrigues for technical support and Marilia Martins Cavariani for writing assistance. This work was supported by the Coordination for the Improvement of Higher Education Personnel (CAPES) and the State of São Paulo Research Foundation (FAPESP) [2013/07203-4].

\section{References}

[1] P. Liang, L. Zhang, L. Peng, Q. Li, E. Zhao, Determination of phthalate esters in soil samples by microwave assisted extraction and high performance liquid chromatography, Bull. Environ. Contam. Toxicol. 85 (2010) 147-151, http:// dx.doi.org/10.1007/s00128-010-0078-x.

[2] H. Liu, H. Liang, Y. Liang, D. Zhang, C. Wang, H. Cai, et al., Distribution of phthalate esters in alluvial sediment: a case study at JiangHan Plain, Central China, Chemosphere 78 (2010) 382-388, http://dx.doi.org/10.1016/j. chemosphere.2009.11.009.

[3] W. Wang, Y. Zhang, S. Wang, C.Q. Fan, H. Xu, Distributions of phthalic esters carried by total suspended particulates in Nanjing, China, Environ. Monit. Assess. 184 (2012) 6789-6798, http://dx.doi.org/10.1007/s10661-011-2458-z.

[4] M. Wittassek, H.M. Koch, J. Angerer, T. Brüning, Assessing exposure to phthalates - The human biomonitoring approach, Mol. Nutr. Food Res. 55 (2011) 7-31, http://dx.doi.org/10.1002/mnfr.201000121.

[5] J.D. Meeker, S. Sathyanarayana, S.H. Swan, Phthalates and other additives in plastics: human exposure and associated health outcomes, Philos. Trans. R. Soc. Lond. B. Biol. Sci. 364 (2009) 2097-2113, http://dx.doi.org/10.1098/rstb. 2008.0268.

[6] J.W. Chang, B.R. Yan, M.H. Chang, S.H. Tseng, Y.M. Kao, J.C. Chen, et al., Cumulative risk assessment for plasticizer-contaminated food using the hazard index approach, Environ. Pollut. 189 (2014) 77-84, http://dx.doi.org/ 10.1016/j.envpol.2014.02.005.

[7] B.C. Blount, K.E. Milgram, M.J. Silva, N. a Malek, J. a Reidy, L.L. Needham, et al., Quantitative detection of eight phthalate metabolites in human urine using HPLC-APCI-MS/MS, Anal. Chem. 72 (2000) 4127-4134, http://dx.doi.org/10. 1289/ehp.6663.

[8] N. Jornet-Martínez, C. Antón-Soriano, P. Campíns-Falcó, Estimation of the presence of unmetabolized dialkyl phthalates in untreated human urine by an on-line miniaturized reliable method, Sci. Total Environ. 532 (2015) 239-244, http://dx.doi.org/10.1016/j.scitotenv.2015.05.124.

[9] P.H. Su, C.K. Chang, C.Y. Lin, H.Y. Chen, P.C. Liao, C.A. Hsiung, et al., Prenatal exposure to phthalate ester and pubertal development in a birth cohort in central Taiwan: a 12-year follow-up study, Environ. Res. 136 (2015) 324-330, http://dx.doi.org/10.1016/j.envres.2014.10.026.

[10] E. Mylchreest, D.G. Wallace, R.C. Cattley, P.M. Foster, Dose-dependent alterations in androgen-regulated male reproductive development in rats exposed to Di(n-butyl) phthalate during late gestation, Toxicol. Sci. 55 (2000) 143-151, http://dx.doi.org/10.1093/toxsci/55.1.143.

[11] H.S. Kim, T.S. Kim, J.-H. Shin, H.J. Moon, I.H. Kang, I.Y. Kim, et al., Neonatal exposure to di(N-Butyl) phthalate (Dbp) alters male reproductive-Tract development, J. Toxicol. Environ. Heal. Part A. 67 (2004) 2045-2060, http:// dx.doi.org/10.1080/15287390490514859.

[12] W.R. Scarano, F.C. Toledo, M.T. Guerra, P.F.F. Pinheiro, R.F. Domeniconi, S.L. Felisbino, et al., Functional and morphological reproductive aspects in male rats exposed to di-n-butyl phthalate (DBP) in utero and during lactation, J. Toxicol. Environ. Health A 73 (2010) 972-984, http://dx.doi.org/10.1080/ 15287391003751760.

[13] J. Jiang, L. Ma, L. Yuan, X. Wang, W. Zhang, Study on developmental abnormalities in hypospadiac male rats induced by maternal exposure to di-n-butyl phthalate (DBP), Toxicology 232 (2007) 286-293, http://dx.doi.org/ 10.1016/j.tox.2007.01.018.

[14] J.T. Jiang, W.L. Sun, Y.F. Jing, S.B. Liu, Z. Ma, Y. Hong, et al., Prenatal exposure to di-n-butyl phthalate induces anorectal malformations in male rat offspring, Toxicology 290 (2011) 323-327, http://dx.doi.org/10.1016/j.tox.2011.10.008.

[15] U.M. Bello, M.C. Madekurozwa, H.B. Groenewald, T.A. Aire, A. Arukwe, The effects on steroidogenesis and histopathology of adult male Japanese quails (Coturnix coturnix japonica) testis following pre-pubertal exposure to di(n-butyl) phthalate (DBP), Comp. Biochem. Physiol. Part - C Toxicol. Pharmacol. 166 (2014) 24-33, http://dx.doi.org/10.1016/j.cbpc.2014.06.005.

[16] A.R. Peixoto, T.M. Santos, J.Z. Brandt, F.K. Delella, B.F. Gonçalves, S.G.P. Campos, et al., Gestational and lactational exposition to di-Nbutyl- phthalate (DBP) increases inflammation and preneoplastic lesions in prostate of wistar rats after carcinogenic N-Methyl-N-nitrosourea (MNU) plus testosterone protocol, Environ. Toxicol. (2015), http://dx.doi.org/10.1002/tox.22126.

[17] P. Corbier, P. Martikainen, J. Pestis, P. Härkönen, Experimental Research on the Morphofunctional Differentiation of the Rat Ventral Prostate: roles of the Gonads at Birth experimental on the morphofunctional differentiation of the rat ventral prostate: roles of the gonads, Arch. Physiol. Biochem. 3455 (1995), http://dx.doi.org/10.3109/13813459508998139.

[18] M. Ema, E. Miyawaki, K. Kawashima, Critical period for adverse effects on development of reproductive system in male offspring of rats given di-n-butyl phthalate during late pregnancy, Toxicol. Lett. 111 (2000) 271-278, http://dx.doi.org/10.1016/S0378-4274(99)00192-7.

[19] E. Mylchreest, M. Sar, D.G. Wallace, P.M.D. Foster, Fetal testosterone insufficiency and abnormal proliferation of Leydig cells and gonocytes in rats exposed to di(n-butyl) phthalate, Reprod. Toxicol. 16 (2002) 19-28, http://dx. doi.org/10.1016/S0890-6238(01)00201-5.

[20] K.L. Howdeshell, C.V. Rider, V.S. Wilson, L.E. Gray, Mechanisms of action of phthalate esters, individually and in combination, to induce abnormal reproductive development in male laboratory rats, Environ. Res. 108 (2008) 168-176, http://dx.doi.org/10.1016/j.envres.2008.08.009.

[21] A.J. Martino-Andrade, I. Chahoud, Reproductive toxicity of phthalate esters, Mol. Nutr. Food Res. 54 (2010) 148-157, http://dx.doi.org/10.1002/mnfr. 200800312.

[22] L.P. Bustamante-Montes, M.A. Hernández-Valero, D. Flores-Pimentel, M. García-Fábila, A. Amaya-Chávez, D.B. Barr, et al., Prenatal exposure to phthalates is associated with decreased anogenital distance and penile size in 
male newborns, J. Dev. Orig. Health Dis. 4 (2013) 300-306, http://dx.doi.org/ $10.1017 /$ S2040174413000172.

[23] C. Xie, Y. Zhao, L. Gao, J. Chen, D. Cai, Y. Zhang, Elevated phthalates' exposure in children with constitutional delay of growth and puberty, Mol. Cell. Endocrinol. 407 (2015) 67-73, http://dx.doi.org/10.1016/j.mce.2015.03.006.

[24] N.J. Barlow, P.M.D. Foster, Pathogenesis of male reproductive tract lesions from gestation through adulthood following in utero exposure to $\mathrm{Di}(\mathrm{n}$-butyl) phthalate, Toxicol. Pathol. 31 (2003) 397-410, http://dx.doi.org/10.1080/ 01926230390202335 .

[25] E. Mylchreest, R.C. Cattley, P.M. Foster, Male reproductive tract malformations in rats following gestational and lactational exposure to $\mathrm{Di}(\mathrm{n}$-butyl) phthalate: an antiandrogenic mechanism? Toxicol. Sci. 43 (1998) 47-60, http://dx.doi.org/10.1006/toxs.1998.2436.

[26] M. Welsh, G. Yamada, The masculinization programming window, Endocr. Dev. 27 (2014) 17-27, http://dx.doi.org/10.1159/000363609.

[27] G.S. Prins, O. Putz, Molecular signaling pathways that regulate prostate gland development, Differentiation 76 (2008) 641-659, http://dx.doi.org/10.1111/j. 1432-0436.2008.00277.x.

[28] Y. Pu, L. Huang, L. Birch, G.S. Prins, Androgen regulation of prostate morphoregulatory gene expression: fgf10-dependent and -independent pathways, Endocrinology 148 (2007) 1697-1706, http://dx.doi.org/10.1210/ en.2006-1113.

[29] G.R. Cunha, B. Foster, A. Thomson, Y. Sugimura, N. Tanji, M. Tsuji, et al., Growth factors as mediators of androgen action during the development of the male urogenital tract, World J. Urol. 13 (1995) 264-276, http://dx.doi.org/ 10.1007/BF00185969.

[30] J.J. Adibi, R. Hauser, P.L. Williams, R.M. Whyatt, A.M. Calafat, H. Nelson, et al., Maternal urinary metabolites of Di-(2-ethylhexyl) phthalate in relation to the timing of labor in a US multicenter pregnancy cohort study, Am. J. Epidemiol. 169 (2009) 1015-1024, http://dx.doi.org/10.1093/aje/kwp001.

[31] P.S. Cooke, P. Young, G.R. Cunha, Androgen receptor expression in developing male reproductive organs, Endocrinology 128 (1991) 2867-2873, http://dx. doi.org/10.1210/endo-128-6-2867.

[32] P.C. Marker, A.A. Donjacour, R. Dahiya, G.R. Cunha, Hormonal, cellular, and molecular control of prostatic development, Dev. Biol. 253 (2003) 165-174, http://dx.doi.org/10.1016/S0012-1606(02)00031-3.

[33] C. Grisanzio, S. Signoretti, p63 in prostate biology and pathology, J. Cell. Biochem. 103 (2008) 1354-1368, http://dx.doi.org/10.1002/jcb.21555.

[34] G.S. Prins, C. Woodham, M. Lepinske, L. Birch, Effects of neonatal estrogen exposure on prostatic secretory genes and their correlation with androgen receptor expression in the separate prostate lobes of the adult rat, Endocrinology 132 (1993) 2387-2398.

[35] G.S. Prins, L. Huang, L. Birch, Y. Pu, The role of estrogens in normal and abnormal development of the prostate gland, Ann. N. Y. Acad. Sci. 2006 (2016) 1-13, http://dx.doi.org/10.1196/annals.1386.009.

[36] T.L. Timme, L.D. Truong, V.W. Merz, T. Krebs, D. Kadmon, K.C. Flanders, et al. Mesenchymal-epithelial interactions and transforming growth factor-beta expression during mouse prostate morphogenesis, Endocrinology 134 (1994) 1039-1045 http://www.ncbi.nlm.nih.gov/pubmed/8119140.

[37] F.W. George, K.G. Peterson, 5??-Dihydrotestosterone formation is necessary for embryogenesis of the rat prostate, Endocrinology 122 (1988) 1159-1164.

[38] A. Omori, S. Miyagawa, Y. Ogino, M. Harada, K. Ishii, Y. Sugimura, et al., Essential roles of epithelial bone morphogenetic protein signaling during prostatic development, Endocrinology 155 (2014) 2534-2544, http://dx.doi. org/10.1210/en.2013-2054.

[39] G.P. Risbridger, G.A. Almahbobi, R.A. Taylor, Early prostate development and its association with late-life prostate disease, Cell Tissue Res. 322 (2005) 173-181, http://dx.doi.org/10.1007/s00441-005-1121-9.

[40] J. Boberg, H.K.L. Johansson, N. Hadrup, K. Dreisig, L. Berthelsen, K. Almstrup, et al., Perinatal exposure to mixtures of anti-androgenic chemicals causes proliferative lesions in rat prostate, Prostate 75 (2015) 126-140, http://dx.doi. org/10.1002/pros.22897.

[41] C.F. Pinho, M.A. Ribeiro, J.C. Rinaldi, S.L. Felisbino, P.F. Pinheiro, R.F. Domeniconi, et al., Gestational protein restriction delays prostate morphogenesis in male rats, Reprod. Fertil. Dev. 26 (2014) 967-973, http://dx. doi.org/10.1071/RD13132.

[42] M. Bradford, A rapid and sensitive method for the quantiWcation of microgram quantities of protein utilizing the principle of protein-dye binding, Anal. Biochem. 72 (1976) 248-254.

[43] W.J. Rogan, Pollutants Milk, Arch. Pediatr. Adolesc. Med. 150 (1996) 981-990.

[44] H. Takeda, T. Mizuno, I. Lasnitzki, Autoradiographic studies of androgen-binding sites in the rat urogenital sinus and postnatal prostate, J.Endocrinol 104 (1985) 87-92.

[45] A. Bischoff, M.A. Levitt, A. Peña, Update on the management of anorectal malformations, Pediatr. Surg. Int. 29 (2013) 899-904, http://dx.doi.org/10. 1007/s00383-013-3355-z.

[46] W.R. Scarano, F.C. de Toledo, M.T. Guerra, S.G.P. de Campos, L.A.J. Júnior, S.L. Felisbino, et al., Long-term effects of developmental exposure to di-n-butyl-phthalate (DBP) on rat prostate: proliferative and inflammatory disorders and a possible role of androgens, Toxicology 262 (2009) 215-223 http://dx.doi.org/10.1016/j.tox.2009.06.011.

[47] P.M.D. Foster, Disruption of reproductive development in male rat offspring following in utero exposure to phthalate esters, Int. J. Androl. 29 (2006) 140-147, http://dx.doi.org/10.1111/j.1365-2605.2005.00563.x (discussion 181-185).
[48] K. Jarfelt, M. Dalgaard, U. Hass, J. Borch, H. Jacobsen, O. Ladefoged, Antiandrogenic effects in male rats perinatally exposed to a mixture of di(2-ethylhexyl) phthalate and di(2-ethylhexyl) adipate, Reprod. Toxicol. 19 (2005) 505-515, http://dx.doi.org/10.1016/j.reprotox.2004.11.005.

[49] M. Aydogan Ahbab, N. Barlas, Developmental effects of prenatal di-n-hexyl phthalate and dicyclohexyl phthalate exposure on reproductive tract of male rats: postnatal outcomes, Food Chem. Toxicol. 51 (2013) 123-136, http://dx. doi.org/10.1016/j.fct.2012.09.010.

[50] C.C. Korenbrot, I.T. Huhtaniemi, R.I. Weiner, Preputial separation as an external sign of pubertal development in the male rat, Biol. Reprod. 17 (1977) 298-303, http://dx.doi.org/10.1095/biolreprod17.2.298.

[51] C.M. Carruthers, P.M.D. Foster, Critical window of male reproductive tract development in rats following gestational exposure to di-n-butyl phthalate, Birth Defects Res. Part B - Dev. Reprod. Toxicol. 74 (2005) 277-285, http://dx. doi.org/10.1002/bdrb.20050.

[52] C. Xie, Y. Zhao, L. Gao, J. Chen, D. Cai, Y. Zhang, Elevated phthalates' exposure in children with constitutional delay of growth and puberty, Mol. Cell. Endocrinol. 407 (2015) 67-73, http://dx.doi.org/10.1016/j.mce.2015.03.006.

[53] Epa, Guidelines for Reproductive Toxicity Risk Assessment Response. vol. 61 1996 56274-56322. http://www.epa.gov/raf/publications/guidelinesreproductive-tox-risk-assessment.htm.

[54] E. Mylchreest, M. Sar, R.C. Cattley, P.M. Foster, Disruption of androgen-regulated male reproductive development by di(n-butyl) phthalate during late gestation in rats is different from flutamide, Toxicol. Appl. Pharmacol. 156 (1999) 81-95, http://dx.doi.org/10.1006/taap.1999.8643.

[55] L.G. Parks, J.S. Ostby, C.R. Lambright, B.D. Abbott, G.R. Klinefelter, N.J. Barlow, et al., The plasticizer diethylhexyl phthalate induces malformations by decreasing fetal testosterone synthesis during sexual differentiation in the male rat, Toxicol. Sci. 58 (2000) 339-349, http://dx.doi.org/10.1093/toxsci/58. 2.339 .

[56] P. Fomby, A.J. Cherlin, NIH Public Access 72 (2011) 181-204, http://dx.doi.org/ 10.1038/nature13314.A.

[57] C. Wolf, C. Lambright, P. Mann, M. Price, R.L. Cooper, L.E. Gray, Administration of potentially antiandrogenic pesticides (procymidone, linuron, iprodione, chlozolinate, p, p X -DDE, and ketoconazole) and toxic substances (dibutyland diethylhexyl phthalate, PCB 169, and ethane dimethane sulphonate) during, (1999) 94-118.

[58] P.M.D. Foster, R.C. Cattley, E. Mylchreest, Effects of di-n-butyl phthalate (DBP) on male reproductive development in the rat: implications for human risk assessment, Food Chem. Toxicol. (2000), http://dx.doi.org/10.1016/s02786915(99)00128-3.

[59] S. Moody, H. Goh, A. Bielanowicz, P. Rippon, K.L. Loveland, C. Itman, Prepubertal mouse testis growth and maturation and androgen production are acutely sensitive to di- $\mathrm{n}$ - butyl phthalate, Endocrinology 154 (2016) 3460-3475, http://dx.doi.org/10.1210/en.2012-2227.

[60] D.N.R. Veeramachaneni, G.R. Klinefelter, Phthalate-induced pathology in the foetal testis involves more than decreased testosterone production, Reproduction 147 (2014) 435-442, http://dx.doi.org/10.1530/REP-13-0441.

[61] K.L. Howdeshell, J. Furr, C.R. Lambright, V.S. Wilson, B.C. Ryan, L.E. Gray, Gestational and lactational exposure to ethinyl estradiol, but not bisphenol a, decreases androgen-dependent reproductive organ weights and epididymal sperm abundance in the male long evans hooded rat, Toxicol. Sci. 102 (2008) 371-382, http://dx doi.org/10.1093/toxsci/kfm306.

[62] A. Rivas, J.S. Fisher, C. McKinnell, N. Atanassova, R.M. Sharpe, Induction of reproductive tract developmental abnormalities in the male rat by lowering androgen production or action in combination with a low dose of diethylstilbestrol: evidence for importance of the androgen-estrogen balance, Endocrinology 143 (2002) 4797-4808, http://dx.doi.org/10.1210/en.2002220531.

[63] A.P.S. Perez, M.F. Biancardi, R.M. G??es, F.A. dos Santos, S.R. Taboga, Exposure to ethinylestradiol during prenatal development and postnatal supplementation with testosterone causes morphophysiological alterations in the prostate of male and female adult gerbils, Int. J. Exp. Pathol. 92 (2011) 121-130, http://dx.doi.org/10.1111/j.1365-2613.2010.00756.x.

[64] W. Xi, C.K.F. Lee, W.S.B. Yeung, J.P. Giesy, M.H. Wong, X. Zhang, et al., Effect of perinatal and postnatal bisphenol A exposure to the regulatory circuits at the hypothalamus-pituitary-gonadal axis of CD-1 mice, Reprod. Toxicol. 31 (2011) 409-417, http://dx.doi.org/10.1016/j.reprotox.2010.12.002.

[65] J.M. Siegford, S. Hadi Mansouri, C. Ulibarri, Normal ontogeny of perineal muscles and testosterone levels in Mongolian gerbils; response to testosterone in developing females, Anat. Rec. A. Discov. Mol. Cell. Evol. Biol. 275 (2003) 997-1008, http://dx.doi.org/10.1002/ar.a.10118.

[66] P.S.L. Vilamaior, S.R. Taboga, H.F. Carvalho, Postnatal growth of the ventral prostate in Wistar rats: a stereological and morphometrical study, Anat. Rec. - Part A Discov. Mol. Cell. Evol. Biol. 288 (2006) 885-892, http://dx.doi.org/ 10.1002/ar.a.20363.

[67] E. Diamanti-Kandarakis, J.-P. Bourguignon, L.C. Giudice, R. Hauser, G.S. Prins, A.M. Soto, et al., Endocrine-disrupting chemicals: an Endocrine Society scientific statement, Endocr. Rev. 30 (2009) 293-342, http://dx.doi.org/10. 1210/er.2009-0002.

[68] D.M. Walker, B.A. Kermath, M.J. Woller, A.C. Gore, Disruption of reproductive aging in female and male rats by gestational exposure to estrogenic endocrine disruptors, Endocrinology 154 (2013) 2129-2143, http://dx.doi.org/10.1210/ en.2012-2123.

[69] O. Putz, C.B. Schwartz, G. a LeBlanc, R.L. Cooper, G.S. Prins, Neonatal low- and high-dose exposure to estradiol benzoate in the male rat: II. Effects on male 
puberty and the reproductive tract, Biol. Reprod. 65 (2001) 1506-1517, http://dx.doi.org/10.1095/biolreprod65.5.1506.

[70] W.-Y. Hu, G.-B. Shi, D.-P. Hu, J.L. Nelles, G.S. Prins, Actions of estrogens and endocrine disrupting chemicals on human prostate stem/progenitor cells and prostate cancer risk, Mol. Cell. Endocrinol. 354 (2012) 63-73, http://dx.doi. org/10.1016/j.mce.2011.08.032.

[71] D.M. Peehl, Primary cell cultures as models of prostate cancer development, Endocr. Relat. Cancer. 12 (2005) 19-47, http://dx.doi.org/10.1677/erc.1.00795.

[72] H.F. de Carvalho, S.R. Line, Basement membrane associated changes in the rat ventral prostate following castration, Cell Biol. Int. 20 (1996) 809-819 http:// www.ncbi.nlm.nih.gov/pubmed/9032941.

[73] P.S.L. Vilamaior, S.R. Taboga, H.F. Carvalho, Modulation of smooth muscle cell function: morphological evidence for a contractile to synthetic transition in the rat ventral prostate after castration, Cell Biol. Int. 29 (2005) 809-816, http://dx.doi.org/10.1016/j.cellbi.2005.05.006.

[74] S.W. Hayward, M. a Rosen, G.R. Cunha, Stromal-epithelial interactions in the normal and neoplastic prostate, Br. J. Urol. 79 (Suppl. 2) (1997) 18-26, http: dx.doi.org/10.1111/j.1464-410X.1997.tb16917.x.

[75] G.S. Prins, K.S. Korach, The role of estrogens and estrogen receptors in normal prostate growth and disease, Steroids 73 (2008) 233-244, http://dx.doi.org/ 10.1016/j.steroids.2007.10.013.

[76] G.S. Prins, O. Putz, Molecular signaling pathways that regulate prostate gland development, Differentiation 76 (2008) 641-659, http://dx.doi.org/10.1111/j. 1432-0436.2008.00277.x.
[77] L. Huang, Y. Pu, S. Alam, L. Birch, G.S. Prins, The role of Fgf10 signaling in branching morphogenesis and gene expression of the rat prostate gland: lobe-specific suppression by neonatal estrogens, Dev. Biol. 278 (2005) 396-414, http://dx.doi.org/10.1016/j.ydbio.2004.11.020.

[78] B.L.M. Hogan, Bone morphogenetic proteins: multifunctional regulators of vertebrate development, Genes Dev. 10 (1996) 1580-1594, http://dx.doi.org/ 10.1101 /gad.10.13.1580.

[79] L.L. Abler, K.P. Keil, V. Mehta, P.S. Joshi, C.T. Schmitz, C.M. Vezina, A high-resolution molecular atlas of the fetal mouse lower urogenital tract, Dev. Dyn. 240 (2011) 2364-2377, http://dx.doi.org/10.1002/dvdy.22730.

[80] I.B. Grishina, S.Y. Kim, C. Ferrara, H.P. Makarenkova, P.D. Walden, BMP7 inhibits branching morphogenesis in the prostate gland and interferes with Notch signaling, Dev. Biol. 288 (2005) 334-347, http://dx.doi.org/10.1016/j. ydbio.2005.08.018.

[81] G.R. Cunha, E.T. Alarid, T. Turner, A.A. Donjacour, E.L. Boutin, B.A. Foster, Normal and abnormal development of the male urogenital tract. Role of androgens, mesenchymal-epithelial interactions, and growth factors, J. Androl. 13 (1992) 465-475 http://www.ncbi.nlm.nih.gov/pubmed/1293128. 